\title{
gFORSETI
}

\section{Decisión final: ¿Quién se beneficia con las holguras del cronograma en los proyectos de construcción?}

\author{
Gustavo Paredes*
}

Resumen. - En el contexto de las disputas en construcción, este artículo responde a una pregunta frecunte en el análisis de controversias sobre ampliación de plazo y aporta utilidad en simplificar la discusión y sus consecuencias.

\begin{abstract}
In the context of construction disputes, this article responds to a frequent question in the analysis of controversies involving extension of time and helps to simplify the discussion and its consequences.
\end{abstract}

Palabras claves. - Resolución de disputas - Plazo y Holguras.

Keywords. - Dispute Resolution - Time and Floats.

* Socio fundador de la NPG Abogados, especialista en Derecho de la Construcción, Contratación Estatal y Solución de Disputas. Profesor de la Facultad de Derecho y Escuela de Post Grado de la Universidad Universidad del Pacífico y Universidad Peruana de Ciencias Aplicadas. Presidente de la Sociedad Peruana de Derecho de la Construcción. Miembro de la Dispute Resolution Board Foundation (DRBF) y de la International Construction Projects Committee (ICP) de la International Bar Association (IBA).

* Un especial agradecimiento al aporte invalorable de dos abogadas brillantes para este trabajo. Gracias a la Dra. Katherine Waidhofer, Co-líder del equipo de NPG Abogados con quien comparto siempre los retos de diseñar creativamente y defender los casos de la firma; y a la Dra. Sonia Queija, cuya tarea académica -cuando era estudiante- no sólo la obligó a mostrar su mejor potencial de investigación sino que sirvió de soporte para este artículo. 


\section{Introducción}

Este trabajo pretende generar el inicio de una larga discusión académica en el país que ayude al debate interno de los miembros de un dispute board o tribunal arbitral, en la trascendental tarea de emitir una decisión.

El modesto punto de vista expresado en este artículo, no necesariamente puede ser compartido por el lector; y sería muy útil que no lo fuera, para motivar el interés en profundizar el análisis de una controversia muy frecuente en el desarrollo de los proyectos de construcción como lo es la disputa sobre extensión de plazo.

En la ejecución de los proyectos de construcción en el Perú, las controversias sobre extensión de plazo, el cumplimiento de los requisitos de forma de su solicitud y las condiciones de fondo para su otorgamiento, son las disputas más frecuentes que son analizadas y decididas por los órganos de solución de conflictos contractuales.

Dentro de la infinidad de estas discusiones que se entremezclan, hay uno de especial criticidad y de relevante importancia porque en torno al cual gira el análisis de la ruta crítica del cronograma de obra: La holgura.

Para evitar asumir que algunos conceptos estén sobrentendidos, buscaré simplificar la definición de holgura y su relación con la ruta crítica del cronograma de obra.

\section{La holgura y su relación con la ruta crítica del cronograma de obra.}

En palabras sencillas, una holgura es el período, margen o ventana de tiempo entre la fecha más temprana y la fecha más tarde de conclusión de una actividad o partida programada en el cronograma de obra.

Existen tipos de holguras. Una de las clasificaciones más sencillas la explica KELLEY.

KELLEY ${ }^{1}$ diferencia entre las holguras totales y holguras libres. La holgura total la define como la cantidad de tiempo que una actividad programada se puede retrasar sin que se retrase la fecha de finalización del proyecto; $y$, la holgura libre es la cantidad de tiempo que una actividad se puede retrasar sin retrasar el inicio temprano de cualquier otra actividad subsiguiente.

\footnotetext{
"There are two types of float: total float and free float. Total float is the amount of time an activity can be delayed without delaying the project's completion date. An activity's total float is calculated by subtracting either its early start date from its late start date or its early finish date from its late finish date. Any activity with zero total float is a critical activity because a delay in its finish date will delay project completion. Free float is the amount of time an activity can be delayed without delaying the early start of any succeeding activity. Free float will always be less than or equal to total float. An activity on the critical path will have zero free float as well as zero total float."

KELLEY, Gail. Construction Law: An introduction for Engineers, Architects, and Contractors. New Jersey: John Wiley and sons Inc., 2013, p. 130.
} 
Esta clasificación es útil para entender rápidamente una disputa sobre extensión de plazo, ya que partiendo de estos conceptos podremos identificar cual fue la ruta crítica en la planificación del proyecto que muestra el cronograma e identificar también aquellas actividades que no siendo críticas originalmente se volvieron críticas al agotar su holgura.

Pero no se crea que esto es así de sencillo, hay otros autores como VELASCO y CAMPIS² que refiere una tipología más amplia:

“(...) - Holgura de nudo (u oscilación): Es el margen de tiempo de que disponemos para conseguir el suceso. Si su valor es nulo, se dice que el nudo es rígido. (...). - Holgura total: Es el margen de tiempo que queda empezando la actividad lo antes posible y acabándola lo más tarde permisible (...). Holgura libre: es el margen de tiempo que queda empezando la actividad lo antes posible y acabándola también lo antes posible (...). - Holgura independiente: es el margen disponible cuando la actividad anterior ha terminado lo más tarde permisible y se quiere acabar lo más pronto posible $(\ldots)^{\prime \prime}$.

Esta última tipología nos regresa a la realidad de lo complejo que puede expresar una red de actividades y la infinidad de situaciones -o diría mejor- alegaciones que se pueden generar para sustentar el impacto del atraso. Es por ello, que se recurre comúnmente a la explicación de un experto para explicar y sustentar el impacto.

Sin embargo, con independencia de cualquier definición y los tipos de holguras, lo más importante es conocer para qué sirven. Las holguras sirven para mitigar cualquier retraso que razonablemente pueda desviar la secuencia programada y evitar así un estado de mora y la aplicación de una penalidad.

De esta manera, debemos con especial interés centrarnos, preguntar e identificar aquellas actividades programadas que forman parte de la ruta crítica ${ }^{3}$ y luego el impacto que alguna desviación haya generado, ya que justamente la criticidad de cualquier retraso (sea culpable o no al contratista) estará marcada por la inexistencia o el agotamiento de las holguras. La ecuación sería la siguiente: Holgura cero, igual criticidad

Ciertamente, esto tampoco es así de sencillo. Existen proyectos cuyo plazo es un elemento sustancial y crítico para el funcionamiento $u$ operación de una edificación y así de explícito se describe y pacta en el contrato (Ejemplo, la infraestructura contratada para el Proyectos de los Juegos Panamericanos Lima 2019); en estos casos, los contratistas deben hacer su programación con especial

2 VELASCO, Juan y CAMPIS, Juan. Gestión de Proyectos en la empresa: Planificación, programación y control. Madrid: Ediciones Pirámide, 2013, pp. 44-45.

3 Es decir, aquellas actividades que no se pueden retrasar porque atrasarían la fecha de conclusión de la obra. En la guía de PMBOK 6ta Edición 2017. Se define a la ruta crítica como la secuencia de actividades que representa el camino más largo a través de un proyecto, lo cual determina la menor duración posible. 
cuidado y prepararse para ejecutar el proyecto en el menor tiempo posible, y es aquí donde frecuentemente no existen holguras.

Por esta razón, creo importante revisar cómo algunos autores describen o definen el método del camino o ruta crítica para entender su utilidad y también identificar o alertar sus debilidades en la planificación de un proyecto:

i. LLEDÓ y RIVAROLA ${ }^{4}$ sostienen lo siguiente:

"No se puede terminar un proyecto hasta que finalice la ruta de actividades de mayor duración. Al conjunto de estas actividades se lo denomina ruta crítica.

El método de la ruta crítica estima una fecha temprana y una tardía para el inicio y fin de cada actividad del proyecto. El objeto de este método es calcular las holguras para determinar cuáles son las actividades con menor flexibilidad en la agenda del proyecto.

Una forma de identificar las actividades de la ruta crítica es encontrar qué actividades tienen menor holgura. Para ello, se resta el tiempo de terminación más temprano del tiempo de terminación más tardío para cada actividad. Alternativamente, se llega al mismo resultado restando el tiempo de inicio más temprano del tiempo de inicio más tardío".

ii. LEVIN lo describe así:

"It is customary for a contractor to create, whether contractually required or not, some type of progress Schedule that defines how the job will be performed, as well as submit regular updates to measure actual progress and reaffirm established completion dates. Schedules can be in the form of bar charts, flowcharts or critical path method (CPM) network diagrams. During actual performance of the job, other schedule can come into play, such as short-interval or look-ahead schedules, which break larger, overall project schedules into more detailed tasks for immediately upcoming phases of work. In all these cases, schedules are used to plan the work, and later on, are analyzed to determine responsibility for delays encountered on the project $(\ldots)^{5 \prime}$.

"A CPM schedule can provide an effective tool for demonstrating schedule cause and effect relationships. CPMs are especially helpful for determining project impact arising from time-related problems, such as delays, suspensions, or accelerations ${ }^{6 "}$.

iii. KLEE define este método de manera siguiente:

"The critical path method is, therefore, the process of describing the critical activities in a programme by tracing the logical sequence of tasks that directly affect the date of Project completion. It is a methodology or management technique that determines a project's critical path. The resulting programme may be depicted in a number of different forms, including a Grantt or bar chart, a line-of-balance diagram, a pure

4 LLEDÓ, Pablo y RIVAROLA, Gustavo. Gestión de proyectos: Cómo dirigir proyectos exitosos, coordinar los recursos humanos y administrar los riesgos. Buenos Aires: Pearson Education, 2007, p. 51.

5 LEVIN, Paul. Construction contract claims, changes and dispute resolution. Segunda edición. U.S.A.: American Society of Civil Engineers Press, 1998, p. 74.

6 Ibid., p. 76. 
logic diagram, a time-scaled logic diagram or as a time-chain diagram, depending on the nature of the works represented in the programme ${ }^{7 "}$.

iv. KASTOR y SIRAKOULIS no solo describen el método CPM sino que además encuentran una debilidad en él:

"The CPM [Critical Path Method] has been widely used for project scheduling, helping managers to guarantee the in time and on budget completion of the project. CPM provides useful information for the project, such as the critical path(s) and free and total float, which are essential for the efficient planning of a project. An advantage of CPM is the ability of managing by exceptions (critical and near critical activities) especially in large-scale projects. However, CPM is based on the assumption that there are unlimited resources for the execution of the activities. Though in real projects, resources are not unlimited. Thus, scheduling without considering resource constraints gives unreliable schedules ${ }^{8 \prime}$.

El CPM (Critical Path Method) es actualmente el método estándar y más usado en la industria de la construcción. Este método muestra la planificación de actividades con precisión de inicio y fin, y que se conectan entre sí en relación de logicidad. Esta conexión muestra la secuencia de ejecución de la obra. Esta relación de logicidad se expresa en la relación de actividades: Fin-comienzo, comienzocomienzo, fin-fin y comienzo-fin.

En este contexto, si una actividad programada se retrasa suceden dos situaciones: (i) Afecta la conclusión de la obra (holgura cero); y (ii) No afecta la conclusión (holgura); por lo tanto, la ruta que no tiene holgura es la que se conoce como ruta crítica.

\section{Identificación del problema}

En el contexto del debate previo a una decisión final, el dilema que debe ser resuelto en la discusión es: ¿A quién le corresponde tomar para sí el beneficio de una holgura?, ¿al contratista?, ¿al propietario?, ¿a ambos? ${ }^{9} \mathrm{o}$ ¿el beneficiario debe ser el proyecto?

El problema identificado es que no existe una posición uniforme a nivel internacional que defina completamente el dilema. En los Estados Unidos y el Reino Unido, las Cortes no han tenido un tratamiento unánime en este punto; sin embargo, la tendencia es que las holguras le pertenecen al proyecto, en consecuencia, pueden ser utilizadas por cualquiera de las partes, bajo determinadas reglas.

En el Perú, la ausencia de precedentes jurisprudenciales que defina la asignación de las holguras en los proyectos de construcción crea el ambiente para el debate,

7 KLEE, Lucas. International Construction Contract Law. Primera Edición. Reino Unido: Wiley and Sons Ltd, 2015, 132.

8 KASTOR, A y SIRAKOULIS, K. The effectiveness of resource levelling tools for Resource Constraint Project Scheduling Problem. En International Journal of Project Management, vol. 27, núm. 5, 2008, p. 493.

9 Considerando un método de entrega de proyecto integrado o "integrated". 
que es saludable promover para ver que normas del régimen privado o público serían las más cercanas a resolver el dilema.

\section{IV. ¿Por qué es útil resolver este dilema?}

Dilucidar este dilema es útil para definir la imputación de responsabilidad por el retraso en el plazo de una actividad programada, para verificar la criticidad de una actividad de la ruta crítica, para la determinación de los días de extensión de plazo y costos asociados ${ }^{10}$, para la aplicación de penalidades por incumplimiento entre otras controversias, como bien apunta LEVIN: "Allocation of float time has been a source of controversy in disputes involving delays, suspensions and change orders 11".

En estos años, he comprobado que la gran mayoría de los contratistas tienen una percepción negativa del "atraso" y ello se debe de desmitificar. Por supuesto que el atraso tiene una connotación negativa, pero sólo si el atraso en el plazo de ejecución del contrato se debe al retraso culpable del contratista; de otro modo, la connotación positiva será su derecho a solicitar una extensión de tiempo y costo que debe ser otorgado por el comitente.

Como se aprecia entonces, todo lo dicho hasta aquí tiene que ver con la delimitación de los derechos y obligaciones que tienen las partes con relación a una desviación generadora de un atraso en el plazo de la obra.

\section{Desarrollo}

Comparto con KLEE ${ }^{12}$ la opinión que el plazo debe ser uno de los componentes más relevantes en la gestión de proyectos de construcción, fuente de una de las cláusulas más importantes de los contratos y nunca exenta de aspectos controvertidos, al contrario ${ }^{13}$.

10 Siempre que exista una adecuada integración entre la programación de actividades en el cronograma de obra con los costos. La programación del plazo de obra desalineada con los costos, resta consistencia al consecuente reclamo económico.

11 LEVIN, Paul. Construction contract claims, changes and dispute resolution. Segunda Edición. U.S.A.: American Society of Civil Engineers Press, 1998, p. 81.

12 "The concept of time, particularly in terms of time for completion, is one of the most important legal and managerial aspects in a construction project and ranks among the top priorities of construction project participants. When discussing "time" in a construction context, we usually think of time for completion. However, contracts contain many other specific time-related provisions and issues, for example, reaction periods, periods for mutual notices, fulfilment of partial duties, and so on."

KLEE, Lucas. International Construction Contract Law. Primera Edición. Reino Unido: Wiley and Sons Ltd, 2015, p. 128.

13 "Delays may be caused by the employer, the contractor, the contract administrator, third parties or by reasons beyond the parties' control. This may lead to an extension of time for completion (EOT). Sometimes only some works (activities) are delayed and do not require an extension of time for completion, but may result in disruption, i.e. more difficult working conditions.

Delay may lead to damages on the employer's side and are typically in the form of:

- Delayed yield (or public benefit) from an investment;

- Increase in the price of the work and respective complications in relation to lenders;

- Defective cash flow; (...)

If found responsible, the contractor may be sanctioned or be ordered to pay damages, in the form of:

- Contractual penalty/delay damages; 
Esta es la razón que justifica dedicarle un tiempo a la discusión sobre las holguras y conocer cómo han sido tratadas y/o propuestas a nivel internacional para luego intentar una respuesta en el contexto nacional.

\section{i. Experiencia Internacional}

\section{a) Federación Internacional de Ingeniero Consultores (FIDIC)}

Como expresión de las buenas prácticas de la industria, es importante empezar cuestionando ¿Cuál ha sido la posición de FIDIC al respecto?. KLEE ${ }^{14}$ lo explica:

"At first glance, it seems that the FIDIC Red and Yellow Books do not regulate the manner in how time extensions should be actually presented, evaluated and determined. Is it really so? By cross-referencing the relevant Sub-Clauses 8.2, 8.3, 8.4 and 10.1 of the general conditions of the contract of the FIDIC Red and Yellow Books, it is possible to determine appropriate time extension quantum methodologies and to resolve the float ownership question unambiguously. (...)

Sub-Clause 8.4 concludes by confirming that the total of all extensions of time, either for the works or for a particular section, cannot be subsequently decreased. This is so even if a number of omissions are instructed as variations and the contractor is able to achieve completion sooner than is required under Sub-Clause 8.2. The employer or engineer is not then empowered to reduce the time for completion in this respect. The terminal float therefore legitimately belongs to the contractor. (...) Cross referencing and literal interpretation of Sub-Clauses 8.2, 8.4 and 10.1 clearly establish the fact that the contractor owns any float existing between its "originally as planned completion date of the Project" (the PCD) and the "date of time for completion" agreed in the contract (the CCD)"

En línea con el autor, encontramos que la interpretación sistemática de las Subcláusulas 8.2, 8.3, 8.4 y 10.1 de las Condiciones Generales de los Libros Rojo y Amarillo de la edición 1999 se mantiene vigente en la actual edición 2017 de los referidos libros (Subcláusula 8.5), lo que permite sostener que bajo la filosofía FIDIC las holguras le pertenecen y están en beneficio legítimo del contratista.

\section{b) Experiencia Estados Unidos}

La corriente doctrinaria de los Estados Unidos se inclina en atribuir la propiedad de las holguras al "proyecto", a menos que, la holgura esté específicamente asignada en el contrato; es decir, si el contrato contiene una previsión clara al respecto no existe más discusión. De no existir esta expresa atribución, cualquiera de las partes puede servirse de una holgura en el cronograma, observando la regla "first-come, first-served"; es decir, el primero que pretenda su utilización será a quien le corresponda, pero siempre que -y esto es fundamental- actúe de buena fe.

- Damage compensation;

- Loss of performance bonuses (...)".

KLEE, Lucas. International Construction Contract Law. Primera Edición. Reino Unido: Wiley and Sons Ltd, 2015, pp. 128-129.

$14 \quad$ Ibid., pp. 134-143. 
Así lo confirma KELLEY:

"Issues often arise if the owner does something that reduces the float in the schedule, thus depriving the contractor of scheduling flexibility. Unless float is specifically addresses in the contract, however, most courts hold that it is a resource that belongs to the project, and that it can be used by any party on a first-come, first-served basis, as long as the party acts in good faith will not be held liable for a project delay, even if the party delayed an activity until its float was exhausted. Although disputes over how changes affect float are typically over total float, free float values can also be important, particularly when there are resource constraints $15^{\prime \prime}$.

Por su lado, LEVIN remarca:

"In other words, the float belongs to neither party but is for the use of both parties. If the owner orders 10-day suspensions of an activity, the contractor is still on schedule and has five days float left on that activity. Subsequently, the contractor falls behind in his work by 20day, finishes the contract five days late but is not granted a contract extension. Why? Because at the time the suspension occurred, the overall contract completion date was not affected. If the contractor, however, was 10 days late on the item before the suspension occurred (and had only five days float on the item), he would then be entitled to a five-day contract extension ${ }^{16 " .}$

Finalmente, KELLEHER, MASTIN y ROBEY sostienen que:

"There can be a difference between owners and contractors as to who "owns" float. Some government agencies and private owners have begun to use clauses specifically dealing with ownership of float. Two possible solutions to this issue have been suggested. One position is that the contractor owns float. In that contexts, the owner may use float without cost unless and until the contractor can show it needed that same float for its own planning and performance purposes. Once the contractor can show a need for the float that the owner has taken, the owner must compensate the contractor for taking the float.

The alternative and much more common position is that float belongs to the party that first uses it and no party can complain if the other consumes float for its own purposes ${ }^{17 "}$.

Estos tres autores muestran de la tendencia doctrinal mayoritaria con relación a la titularidad de las holguras en los EEUU; sin embargo, hay posiciones diferentes como la de KNOWLES para quien no existe una regla rígida o exacta para atribuir la holgura.

KNOWLES considera que las holguras son del contratista, ya que es él quien normalmente las incluye en el cronograma para manejar los riesgos que algún evento pueda impactar la ejecución de la obra:

15 KELLEY, Gail. Construction Law: An introduction for Engineers, Architects, and Contractors. New Jersey: John Wiley and sons Inc., 2013, p. 130.

16 LEVIN, Paul. Construction contract claims, changes and dispute resolution. Segunda edición. U.S.A.: American Society of Civil Engineers Press, 1998, p. 81.

17 KELLEHER, Thomas; MASTIN, John y ROBEY, Ronald. Smith, Currie E Hancock's common sense construction law: A practical Guide for the Construction Professional. Quinta edición. New Jersey: John Wiley \& sons Inc., 2015, p. 372. 
"There is no hard and fast rule as to who owns float, but it would seem that, as a contractor will normally include float in his programme to accommodate his risk items which cannot be accurately predetermined in terms of time involvement and also to provide time for correcting mistakes, then the float belongs to him and the employer or architect/engineer cannot object if later reprogramming by the contractor absorbs it. This is supported by legal decisions made in the USA18".

El autor refiere que su posición se sostiene en base jurisprudencial citando para sustentar su posición los casos Natken y Co. vs George A Fuller \& Co (1972) y el caso de Ascon Contracting Ltd vs McAlpine Construction (1999) ${ }^{19}$.

\section{c) Experiencia Reino Unido}

La Sociedad de Derecho de la Construcción de Reino Unido elaboró y publicó en el 2002 y en segunda edición en febrero del 2017, el Protocolo de Delay \& Disruption. Este protocolo sirve de guía para el tratamiento específico de los atrasos e interferencias en los proyectos y sus principios pueden ser incorporados por referencia a los contratos de construcción.

En la edición de 2017 del referido Protocolo, se indica que la holgura no es del uso y beneficio exclusivo ni del propietario ni del contratista; $y$ en tanto no exista una disposición expresa en el contrato, la holgura pertenecería al proyecto.

El Core Principle 8 del Protocolo trata sobre la relación entre la holgura y las extensiones de plazo; y señala:

"Float values in a programme are an indication of the relative criticality of activities and, generally, when float is exhausted, the completion date will be impacted. Unless there is express provision to the contrary in the contract, where there is remaining

18 KNOWLES, Roger. 200 Contractual problems and their solutions. Tercera edición. Reino Unido: Wiley and sons Ltd, 2012, p. 88.

19 "A prudent contractor will always include an element of float in his programme to accommodate these variables. (...)

In an earlier case, the Army Corporation of Engineer's Board of Contract Appeals had recognized the contractor's right to reprogramme, thereby giving him the benefit of the float. American Courts also took the line on a management dispute that total float may be used to programme jobs for all contractors; free float belongs to one contractor for programming any one activity. Neither total float or free float should be used for changes, that is, variations, as expressed in Natken and Co v. George A FullerE Co (1972).

The matter of float was in evidence in the case of Ascon Contracting Ltd v. McAlpine Construction (1999). McAlpine was the main contractor for the construction of a five-storey building known as Villiers Development in Douglas, Isle of Man, near to the sea front. Ascon was appointed as subcontractor for constructing the reinforced concrete floor slabs, basement perimeter walls and upright columns between floors. The subcontract period was 29 weeks, commencing on 28 August 1996, with completion by 5 March 1997. (...)

McAlpine's case against Ascon was that, had all subcontractors started and finished on time and McAlpine executed their own work on time, practical completion would have been achieved 5 weeks early. McAlphine's argument was that the five weeks' float was for their benefit, to absorb their own delays. As the five weeks had been used by Ascon and other subcontractors, McAlphine claimed they were entitled to recover their lost benefit.

The judge rejected this argument. He considered the float to be of value in the sense that delays could be accommodated in the float time. This would avoid an overrun to the contract period and, hence, any liability to pay liquidated damages to the employer. The judge went on to say that McAlphine, whilst accepting the benefit against the employer, could not claim against the subcontractors. The judge seems to be taking the view that if float time is available, it can be used in a first come, first served basis. (...)"

Ibid., pp. 86-87. 
total float in the programme at the time of an Employer Risk Event, an EOT should only be granted to the extent that the Employer Delay is predicted to reduce to below zero the total float on the critical path affected by the Employer Delay to Completion (i.e. if the Employer Delay is predicted to extend the critical path to completion)".

Es claro que las holguras en un programa son un indicativo de la relativa criticidad de las actividades y, cuando la holgura se agota, la fecha de terminación será impactada; pero lo más importante que prescribe es que a menos que exista una disposición expresa en contrario en el contrato, es posible entender que la holgura le pertenece al proyecto, siguiendo una lectura sistemática con el numeral 8.5 de la Parte B del Protocolo (Guidance Part B: Guidance on Core Principles) ${ }^{20}$ en la que se concluye que a falta de disposición contractual, la holgura no es de uso exclusivo ni del propietario ni del contratista:

"Core Principle 8 (and 9) set out the Protocol's position on float where the parties in their contract have not made clear provision for how float should be dealt with. This is consistent with current judicial thinking, which is that an Employer Delay has to be critical (to meeting the contract completion date) before an EOT will be due. It has the effect that float is not time for the exclusive use or benefit of either the Employer or the Contractor (unless there is an express provision in the contract)".

\section{ii. Ensayando una respuesta}

Si empezamos por buscar una respuesta en los usos y buenas prácticas de la industria a nivel internacional, parece ser que la posición no es uniforme. Se tiene por un lado, un sector que interpreta que la holgura le corresponde legítimamente al contratista (FIDIC); y, por otro, un sector que señala que aquella no le pertenece ni al contratista ni al propietario sino al proyecto (EEUU y UK) y por tanto le corresponde al primero que se sirve de ella.

Si a esto se añade que en el Perú no existe data doctrinaria ni jurisprudencial que desarrolle este tema específico que pueda ayudar al debate, la tarea no empieza fácil, ya que habría que buscar de algún modo, una aproximación regulatoria que ayude a resolver el dilema planteado.

Así las cosas, ensayar una respuesta, no buscará la razón en sí misma; sino buscará como único reto motivar la reflexión del lector para generar un debate exponencial que logre en el largo plazo crear una tendencia predecible que simplifique la solución de los conflictos relacionados a la extensión de plazo.

Una primera respuesta que podría dejar satisfecha la solución a este dilema sería la siguiente: La parte que se beneficia de la holgura del cronograma de obra será aquella que se establezca así de manera clara, expresa y no ambigua en el contrato; sin embargo, ello no sucede regularmente en la industria. En este segundo escenario, es donde se encuentra la dificultad, porque para llegar a alguna

20 Sociedad de Derecho de la Construcción de Reino Unido. Society of Construction Law Delay and Disruption Protocol Segunda Edición. Leicester: Society of Construction Law (UK), 2017, p. 29. 
respuesta es necesario observar y analizar qué principios o normas se acerca más a esta discusión.

El Código civil peruano hospeda dos principios que sirven de guía de interpretación de sus normas que podrían servir como una primera aproximación para justificar la premisa que las holguras corresponden al contratista. El primero sería el "Principio favor debitoris" y el segundo "Principio del contratista experto".

El Principio favor debitoris ha sido ampliamente recogido en nuestra legislación civil y consiste en interpretar las condiciones contractuales ambigüas o no reguladas de manera clara y expresa, de la forma más favorable al deudor.

PUIG refiere:

"Uno de esos brocardos basados en la equidad - entendida en su acepción clásica cristiana de aplicación benigna y moderada del Derecho - es el favor debitoris, que responde al deseo de suavizar, en los casos dudosos, la situación de los deudores. Algún autor define incidentalmente el favor debitoris como el principio de que "la duda no debe quedar sustituida por una certidumbre del máximo rigor contractual para el obligado, sino con la solución que para el mismo suponga el mínimo rigor" $21 "$.

En esa línea, DIEZ PICAZO señala que:

"Además de la facultad de liberarse de la deuda, el deudor posee la facultad de detener toda pretensión extralimitada o abusiva de su acreedor (por ejemplo, deuda no vencida, pagadera en lugar distinto, prescrita, compensada, etc) (...) El deudor tendrá la facultad de hacer valer una limitación de su responsabilidad en todos aquellos casos en que esta posibilidad le haya sido concedida (...) El deudor es también titular de determinadas facultades que contemplan un normal desarrollo de la relación obligatoria y que tratan de proteger y de tutelar su interés. Por regla general, se entiende que la obligación, en cuanto a limitación de la libertad, debe ser considerada en cierta medida como un supuesto excepcional. El que se obliga, se obliga siempre a lo menos posible. Sobre esta idea toma su base la regla llamada del favor debitoris o de la interpretación más favorable al deudor. Este criterio de favor del deudor aparece en muchos casos en el normal desarrollo de la relación obligatoria. Por ejemplo, corresponde, salvo pacto en contrario, al deudor la facultad de determinar la prestación en el caso de elección en la obligación alternativa o de especificación de la deuda de género; la facultad de anticipar la prestación cuando el plazo se estableció en su exclusivo beneficio; la de reclamar un descuento cuando pagó anticipadamente ignorando la existencia de un plazo [entre otros] ${ }^{22 "}$.

Este principio lo encontramos, por ejemplo, en los siguientes artículos del Código Civil: En el artículo 1162 el cual señala que la elección de la prestación corresponde

21 PUIG BRUTAU, J. Fundamentos de Derecho civil. Tomo II. vol. I. Barcelona: Editorial Bosch, p. 304. Citado por: CASTÁN, José María. El "favor debitoris" en el Derecho Español. Anuario de Derecho Civil, IV, 1961, p. 835.

22 DIEZ PICAZO, Luis. Fundamentos del Derecho Civil Patrimonial. Sexta Edición. Volumen II. Navarra: Editorial Aranzadi S.A., 2008, p. 147. 
al deudor, si no se ha atribuido esta facultad al acreedor o a un tercero; en el artículo 1143 que dispone que en las obligaciones de dar bienes determinados sólo por su especie y cantidad, la elección corresponde al deudor; o en el artículo 179, según el cual el plazo suspensivo se presume establecido en beneficio del deudor, a no ser que del tenor del instrumento o de otras circunstancias, resultase haberse puesto en favor del acreedor o de ambos.

En cuanto al plazo, que es la condición que alberga a la holgura en el contrato de obra, LORENZETTI señala:

"La obligación de entrega puede estar sometida a plazo, con las siguientes características: (...). El plazo puede ser tanto suspensivo, fijando una fecha para el comienzo de las obras, el que debe ser cumplido porque el dueño le interesa cuándo comienza la obra. Si no se cumple, puede intimar el comienzo de la obra, extrajudicial y luego judicialmente, bien resolver el contrato por incumplimiento. Si el empresario no cumple con el plazo inicial, pero sí con el final, puede ser responsabilizado de los mayores costos sufridos si se demuestra que se habría pagado menos si la obra hubiera sido empezada en término, y la obra fuese por el sistema de coste y costos. El plazo puede ser resolutorio, fijando un lapso extintivo de los efectos obligacionales del contrato 23 ".

En la práctica, la finalidad de pactar el inicio y culminación de las obras es reducir la incertidumbre de las partes en torno al tiempo de ejecución y la entrega de la obra. Naturalmente bajo un esquema de Project Delivery System clásico o tradicional, es el contratista quien está en mejor condición de prever o estimar -en base a la información entregada por el propietario- el plazo de ejecución de la obra, a través de la elaboración de un cronograma que defina actividades y su secuencia lógica de desarrollo, basado en los niveles de rendimiento de sus recursos.

En ese sentido, el plazo ofertado por el contratista será la base de su padecimiento, ya que una vez pactado, las partes tendrán muy claro cuando las obras inician y culminan, no antes ni después. Por ello, la contratación del plazo tiene dos efectos: i) primero, que el deudor (contratista) no puede culminar la obra en fecha posterior al plazo pactado, de ser así le serán aplicadas penalidades por su retraso culpable o se utilizarán los remedios legales del artículo 1429 del Código Civil; y ii) segundo, que el acreedor (propietario) no puede exigir la entrega de la obra en una fecha anterior a la establecida, pues antes de dicha fecha la obligación no es exigible al precio originalmente pactado.

Cualquier desviación que ocurra en la planificación del proyecto que impacte en el plazo deberá ser soportada por la holgura prevista en el cronograma para una determinada actividad y cualquier duda, omisión o ambiguëdad respecto a su beneficio, debería corresponder en primer orden al contratista; y esto ¿por qué?, porque en la práctica sino se concede una extensión de plazo por la afectación de

23 LORENZETTI, Ricardo. Tratado de los contratos. Segunda edición. Tomo II. Buenos Aires: Rubinzal-Culzoni Editores, 2004, pp. 725-726. 
la ruta crítica que restituya y deje indemne las condiciones de iniciales de contratación, el propietario (acreedor) estaría exigiendo desproporcionalmente la entrega de la obra en una fecha anterior a la establecida contractualmente.

Adicionalmente, la previsión de una holgura en el cronograma de actividades es parte del conocimiento experto de un contratista en la planificación del proyecto, y en quién recae la obligación legal de hacer la obra en la forma y plazos convenidos como establece el inciso 1 del artículo 1774 del Código Civil: "el contratista está obligado a: 1 . hacer la obra en la forma y plazos convenidos, o en su defecto, en el que se acostumbre".

Esta obligación descrita en este artículo, como también el referido en el artículo 32.6 y 40 de la Ley 30225 - Texto Único Ordenado de la Ley de Contrataciones del Estado aprobado por Decreto Supremo 082-2019-PCM, son expresión del Principio del contratista experto. Este principio ayuda a entender la razón por el que la ley asigna en cabeza del contratista la obligación de hacer la obra en la forma y plazo convenido, y es porque -justamente en su condición de experto- está en mejor posición de saber cómo planificar la ejecución de la obra.

Entonces, ante esta clara asignación de riesgo normativo, tiene total sentido que un contratista diligente busque razonablemente controlar mejor la precaución de asegurar y/o distribuir mejor sus recursos para cumplir con el plazo contratado y así evitar las consecuencias de su incumplimiento.

Como lo han comentado distintos autores internacionales, uno de los motivos por los que se establecen holguras en el cronograma de ejecución de obras es precisamente para crear una garantía a favor del contratista ante eventos no previstos que retrasen sus actividades e impidan cumplir con el plazo contratado.

Siguiendo a KLEE y KNOWLES, las holguras están en beneficio legítimo del contratista, en la medida que su utilidad es lograr la obra en el plazo comprometido y así quedar liberado de su prestación.

Si lo miramos de otra forma, al momento de celebrar el contrato, el acreedor (propietario) manifestó el interés que su obra culmine y sea recibida en una fecha pactada; $y$, por su parte, el deudor expresó el interés de cumplir su prestación de hacer en el plazo convenido. Siendo esto así, no tendría mucho sentido asignar una holgura en beneficio del acreedor (propietario), pues si la obra termina antes no cambiaría en nada su interés en el objeto del contrato ${ }^{24}$. Por el contrario, para el contratista tiene total sentido proteger su interés de conservar -en su beneficiotoda medida de precaución razonable para reducir su riesgo y cumplir con el plazo contratado.

24 Además, si un propietario pudiese retrasar una actividad del cronograma hasta agotar su holgura puede generar que una actividad que no fue crítica originalmente se vuelva crítica y así directamente afecte su interés de lograr su obra a tiempo. 


\section{Decisión final: ¿Quién se beneficia con las holguras del cronograma}

en los proyectos de construcción?

\section{Conclusión}

A manera de conclusión, se propone para el debate que, salvo la existencia de un pacto expreso sobre la titularidad de una holgura en el cronograma de obra, esta holgura se hallará en primer orden en beneficio del contratista. 